\title{
Ten Years' Monitoring of Intertidal Macroalgal Vegetation of Hyogo Prefecture, Northwestern Coast of Honshu, Japan to Assess the Impact of the Nakhodka Oil Spill
}

\author{
Hiroshi Kawai $^{1 *}$, Mitsunobu Kamiya ${ }^{2}$, Teruhisa Komatsu ${ }^{3}$, Masahiro Nakaoka ${ }^{4}$, \\ Tomoko Yamamoto ${ }^{5}$, and the Marine Life Research Group of Takeno ${ }^{6}$ \\ ${ }^{1}$ Kobe University Research Center for Inland Seas, Rokkodai, Nadaku, Kobe 657-8501, Japan \\ ${ }^{2}$ Faculty of Biotechnology, Fukui Prefectural University, Obama, Fukui 917-0003, Japan \\ ${ }^{3}$ Ocean Research Institute, The University of Tokyo, 1-15-1, Minamidai, Nakanoku, Tokyo 164-8639, Japan \\ ${ }^{4}$ Graduate School of Science and Technology, Chiba University, Inage, Chiba 263-8522, Japan \\ ${ }^{5}$ Faculty of Fisheries, Kagoshima University, 4-50-20, Shimoarata, Kagoshima 890-0056, Japan \\ ${ }^{6}$ Takeno Snorkel Center, Takeno, Takeno-cho, Kinosaki, Hyogo 669-6201, Japan
}

\begin{abstract}
In order to understand the impact of the heavy-oil pollution by the 1997 Nakhodka oil spill on the intertidal macroalgal vegetation, we have been monitoring succession in the intertidal flora since 1997 at Oh-ura, Takno, and ImagoUra Cove, Kasumi in Hyogo Prefecture, northwestern coast of Honshu, Japan. We employed two different monitoring methods: 1) The percent cover of macro-algae (seaweeds) in $1 \times 1 \mathrm{~m}$ quadrats along $450 \mathrm{~m}$ intertidal transects parallel to the shoreline were assessed and recorded by photographic imaging until 2002, and for 30-40 m transects of the most heavily polluted areas in 2004 and 2006; 2) The percent cover of macro-algae in $0.5 \times 0.5 \mathrm{~m}$ quadrats along a transect line perpendicular to the shore were recorded and all macrophytes within the quadrat were completely removed to record the wet weight of each taxon (1997-2006). Based on the monitoring data, we conclude that the high intertidal zone at Imago-ura, where a large part of the stranded oil accumulated, suffered the heaviest damage and experienced the slowest recovery. In addition, although the original status of macroalgal vegetation before the impact was not well-documented, it appeared that recovery from the damage caused by the oil pollution required four to five years.
\end{abstract}

Key Words: heavy-oil spill, impact on intertidal vegetation, line transect study, macroalgae

\section{INTRODUCTION}

Oil pollution of the sea is caused by several different sources: through transportation, from fixed installations including offshore production platforms, and other sources including municipal wastes and industrial wastes (Clark 1997). Among these sources, oil spills caused by the tanker operation troubles and ship-wreck of large-scale oil tankers are not very frequent, but the most serious threat to the coastal environments. The sites of ship-wreck are unpredictable, and the areas affected by floating and cast-ashore oils tend to be rather wide up to several hundred $\mathrm{km}$ of cast lines causing serious impacts to the coastal environment. Ship-wrecks tend to occur in narrow channels with strong tidal currents and

*Corresponding author (kawai@kobe-u.ac.jp) often associated with rough weather, and such conditions would spread the pollution to even wider areas, and can also influence remote areas with pristine biodiversities. However, since the area of the pollutions are rather hard to predict, in most cases of the accidents there are no background data of the coastal biodiversities for estimating the impacts. Comprehensive research projects on the effects of spilled oil on intertidal benthic communities were carried out following large spills such as by Torrey Canyon and Exxon Valdes, and they showed that recovery of communities sometimes requires more than a decade not only due to direct effects of spilled oil, but also due to indirect and chronic effects (Southwood and Southward 1978; Peterson 2001; Peterson et al. 2003).

In Japan, although oil spills repeatedly occurred at the coast of Japan since 1970 's, only a few investigations assessing the impacts by heavy-oil spill on coastal ecosystem and the subsequent recovery from the damage 


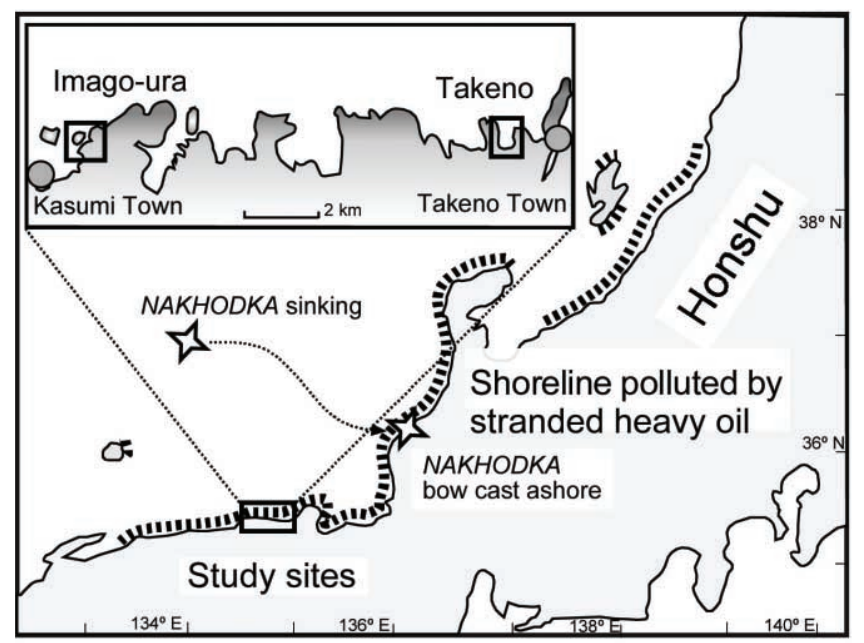

Fig. 1. Overview of the areas polluted by the NAKHODKA oil spill and our study sites (Takeno and Kasumi, Hyogo Pref., Japan).

have been done. For example, the heavy-oil spill at Seto Inland Sea in 1974 gave serious impacts to wide range of coastal area, but the impact on organisms was investigated only for plankton and bacteria communities (Fujiwara \& Murakami 1978, 1981; Kuroda et al. 1978), and not for macro-benthic oranisms.

In 1997, wide area of the northwestern coast of Honshu, Japan suffered serious oil pollution by a broken heavy-oil tanker (Nakhodka oil spill disaster) (Tazaki 2003). The amount of oil reaching the coast of Hyogo Prefecture was not as much as in Fukui Prefecture, where part of the ship was cast ashore, nevertheless the oil pollution caused serious damage to the local coastal ecosystem (Komatsu et al. 2003; Yamamoto et al. 2003a, 2003b). However, due to insufficient pre-disaster baseline data, it was very difficult to qualitatively and quantitatively estimate the actual damage to the coastal biota. After the oil spill, some scientists and regional institutions studied its impacts on benthic animals (Yajima 1997; Hayashi et al. 2000), however, the field survey was conducted only for a short period (no more than one year), precluding evaluation of long-term effects of the spilled oil on benthic communities. Therefore, we initiated two closely-related monitoring projects in order to assess the impact of the oil pollution on the intertidal biota at Takeno and Kasumi, Hyogo Prefecture, northwestern coast of Honshu. We made intensive field studies from 1997 to 2001 and have continued smaller-scale studies until 2006: 1) destructive quadrat sampling along lines perpendicular to the shoreline (line transect studies at Imago-ura and Takeno), and 2) non-destructive sampling parallel to the shoreline (Imago-ura). This paper

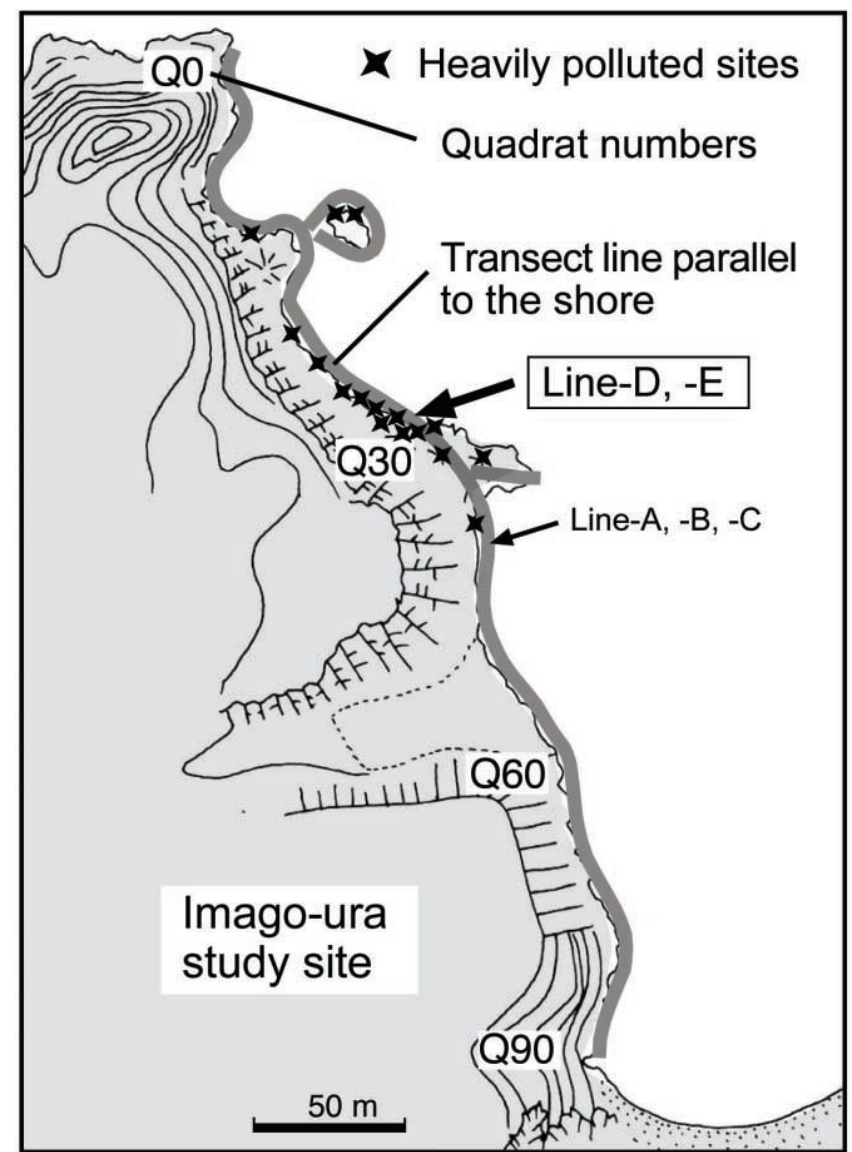

Fig. 2. Location maps of transect lines. a, Oh-ura, Takeno. b, Imago-ura, Kasumi, Hyogo, Japan.

outlines the long-term monitoring projects at Takeno and Imago-ura in Hyogo Prefecture and presents an overview of the data on the macroalgal communities.

\section{MATERIALS AND METHODS}

\section{Study sites and dates}

Figure 1 shows an overview of the areas contaminated by the 1997 Nakhodka oil spill on the northwestern coast of Honshu and the location of our study sites (Imago-ura Cove in Kasumi, and Oh-ura Cove in Takeno, Hyogo Pref., Japan). Only the Imago-ura Cove data (Fig. 2) are presented here. Field studies for the monitoring projects took place on the following dates: 19-20 April, 1997; 1112 April, 7-10 May, 1998; 9-11 April, 7-9 May, 1999; 8-9 April, 12-14 May, 2000; 13-15 April, 12-13 May, 2001; 2021 April, 10-12 May, 2002; 9-11 May, 2003; 22-23 May, 2004; 7-8 May, 2005; and 20-21 May, 2006.

Transects perpendicular to the shoreline (destructive sampling)

Two study sites in Imago-ura Cove (Figs 1,2) were 
Table 1. Subgrouping of 70 research quadrats based on location and bottom conditions

\begin{tabular}{llccl}
\hline Quadrat No. & Main bottom type & Surface complexity & $\begin{array}{c}\text { Level of oil pollution in } \\
\text { spring of 1997 }\end{array}$ & Amount of remaining oil in 1998-2001 \\
\hline Q5-9 & rock and boulder & rough & heavy & light $(<0.1 \%$ of surface $)$ \\
Q10-15 & rock & smooth & heavy & light $(<0.1 \%$ of surface $)$ \\
Q18-23 & boulder & rough & heavy & light $(<0.1 \%$ of surface $)$ \\
Q24-33 & boulder & rough & heavy & moderate $(0.1 \%-1 \%$ of surface $)$ \\
Q34-39 & rock & rough & heavy & light $(<0.1 \%$ of surface $)$ \\
Q45-54 & boulder & smooth & heavy & moderate $(0.1 \%-1 \%$ of surface $)$ \\
Q60-69 & rock & smooth & light & moderate $(0.1 \%-1 \%$ of surface $)$ \\
Q71-82 & concrete and rock & smooth & light & light $(<0.1 \%$ of surface $)$ \\
Q83-91 & concrete & & & light $(<0.1 \%$ of surface $)$ \\
\hline
\end{tabular}

selected, one (transect lines $\mathrm{D}$ and $\mathrm{E}$ ) representing a heavily contaminated area, and the other (lines A, B- and C) representing less contaminated sites in the cove. In the first year of the study (April 1997), the positions of the quadrats $(50 \times 50 \mathrm{~cm})$ were randomly selected with strata representing the high and mid intertidal combined, as well as the upper subtidal (10-12 quadrats at each site). A photographic image record (digital or film) of the vegetation within each quadrat was made prior to sampling. All macroalgae were identified in situ, and the percent cover of each macroalga was estimated. All macroalgae within a quadrat were completely removed using hand scrapers, and the wet weight of each removed species was measured. The position (vertical and horizontal) of the quadrat was recorded using surveying instruments. In the following years, quadrats were selected in adjacent areas, avoiding the quadrats that had been previously sampled. Because of the very small tidal range in the northwestern coast of Honshu (i.e. 0.3-0.4 m), and because of the remarkable variations in the degree of oil pollution and algal vegetation, the area available for destructive sampling was rather limited. Therefore the repetitive sampling necessary for statistical analyses could not be performed.

\section{Transects parallel to the shoreline (non-destructive)}

The western coast of Imago-ura Cove (Figs 1,2) was selected for this study. For the monitoring of macroalgal vegetation, $1 \times 1 \mathrm{~m}$ quadrats were placed to cover the intertidal and upper subtidal zones as much as possible within the $5 \times 5 \mathrm{~m}$ quadrats already established for animal monitoring along the shoreline (c.f. Yamamoto et al. 2003). A photographic image record (digital or film) was made of each quadrat prior to sampling. All macroalgae within each quadrat were identified in situ, and the percent cover of each macroalga was estimated. In general, the positions of the quadrats in this study corresponded to the lower spray zone and the middle intertidal zone of the perpendicular transect study described above.

\section{RESULTS}

\section{General observations}

Within the study area of Imago-ura Cove, the shore around Q30 (Q26-32, Fig. 2) was shown to have suffered the most severe contamination by heavy oil (Table 1). The stranded oil was removed by local people and volunteers using scoops soon after the stranding, but further intensive cleaning by manual wiping was not done in this area. Therefore, a number of oil patches were left on the rocks in the intertidal and spray zones. The tidal range is relatively narrow on the northwestern coast of Honshu (0.3-0.4 $\mathrm{m}$ in this area), and the accumulation of the stranded oil was heavier in the upper intertidal zone (0-0.5 $\mathrm{m}$ above mean water level, corresponding to the shoreward lines in Fig. 3) than in the lower intertidal and subtidal zones (below mean water level, corresponding to the seaward lines in Fig. 3). The surface of the oil patches became crusty after several months, but it took 34 years for the attached oil to become undetectable (Fig. $3)$.

\section{Transects perpendicular to the shoreline (destructive)}

Figure 4 demonstrates the horizontal positions of sampling quadrats from April 1997 to May 2006 (Fig. 4a) and an example of the vertical profile of the transect lines (Fig. $4 \mathrm{~b}$, showing the height and vertical zone of the quadrats in April 2000). As seen in Fig. 4b, along line D, quadrats of $0-1 \mathrm{~m}$ from the starting point (e.g., D-0) represent the spray zone, those of $3-6 \mathrm{~m}$ (as well as $11 \mathrm{~m}$ in this case) represent the intertidal zone, and that of $10 \mathrm{~m}$ represents the upper subtidal zone. Similarly, along line 


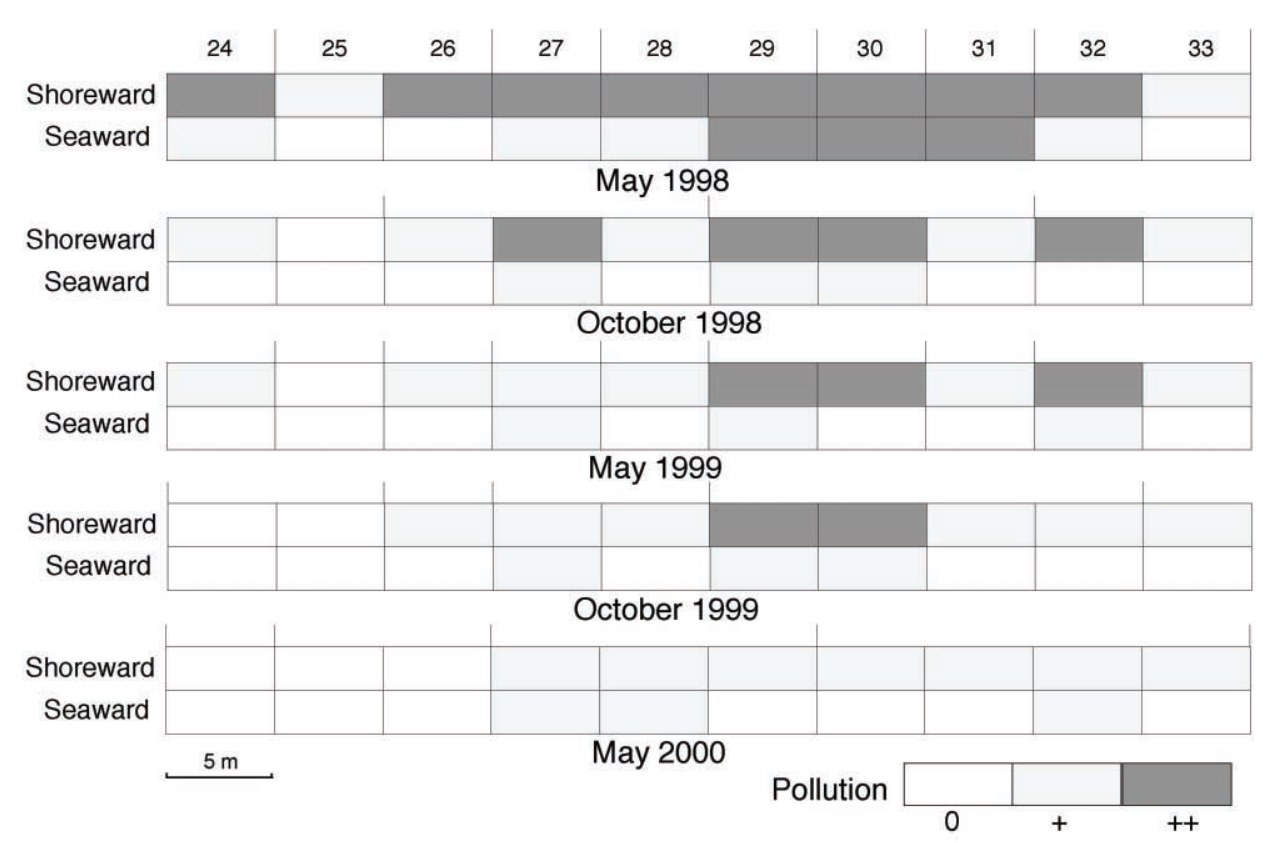

Fig. 3. Degree of oil pollution in each quadrat, and its yearly succession. ++ , indicates severely polluted; + , slightly polluted; 0 , no pollution.

Table 2. Change in number of species and total biomass (wet weight, $\mathrm{g}$ ) of macroalgal species in $0.5 \times 0.5 \mathrm{~m}$ quadrats of transect line E in Imago-ura; nd, no data.

\begin{tabular}{|c|c|c|c|c|c|c|c|c|c|c|}
\hline line /year & 1997 & 1998 & 1999 & 2000 & 2001 & 2002 & 2003 & 2004 & 2005 & 2006 \\
\hline E-1 & $\begin{array}{ll}0 & (0)\end{array}$ & $1 \quad(0)$ & $8 \quad(39)$ & $1 \quad(0)$ & $(0)$ & $0 \quad(0)$ & nd & $0 \quad(0)$ & nd & $0 \quad(0)$ \\
\hline E-3-1 & $1 \quad(10)$ & $6 \quad(4)$ & $9 \quad(55)$ & $11(24)$ & 11 (148) & $14 \quad(55)$ & nd & $13 \quad(6)$ & nd & 7 (97) \\
\hline E-3-2 & $1 \quad$ (5) & $8 \quad(75)$ & $6 \quad(81)$ & 2 (1) & $14 \quad(58)$ & $3(180)$ & nd & nd & nd & 14 \\
\hline E-4 & $1 \quad(0)$ & 11(167) & $8 \quad(42)$ & $6(18)$ & $6(1050)$ & $8(243)$ & nd & $6 \quad(0)$ & nd & $8(173)$ \\
\hline E-5-1 & 10 & $14(349)$ & 10 (378) & $6(26)$ & 10 (209) & $5 \quad(85)$ & nd & 13 (177) & nd & 13 (393) \\
\hline E-5-2 & $8(132)$ & nd & $9(223)$ & $3(50)$ & $13(754)$ & $3(155)$ & nd & nd & nd & 12 (247) \\
\hline
\end{tabular}

E, E-1 represents the lower spray to upper intertidal zone, E-3a, E-3b and E-5 represent the middle and lower intertidal, and E-4 represents the upper subtidal zone, although the height is somewhat variable depending on the year because of the inexact placement of the transects.

Table 2 and Fig. 5 demonstrate the yearly spring changes in total number of species and wet weight along line E (Figs 5a, b, respectively). As seen in Fig. 5a, there was very little vegetation in the spray zone (0-1 species) irrespective of the year (E-1). In contrast, the number of species was generally low in the intertidal quadrats (E-31, E-3-2 and E-4) in 1997, but tended to increase markedly in 1998. In some quadrats, the number increased further (E-1 and E-3-1) in subsequent years, whereas in other quadrats it stayed more or less constant (D-3 and D-6) or declined (E-3-2 and E-4). The number of species was relatively high and stable in the quadrats furthest from the base point and in the subtidal zone (E-5-1 and E-5-2). The change in macroalgal biomass (Fig. 5b, wet weight per quadrat) generally was consistent with the change in the number of species.

\section{Transects parallel to the shoreline (non-destructive)}

Table 3 demonstrates the degree of oil pollution and the number of macroalgal species recorded within each quadrat, in quadrats 26 to 33 from 1998 (one year after the disaster) to 2004. The number of species in each quadrat fluctuated from year to year, but the fluctuation was especially high in some quadrats in heavily polluted areas. For example, in quadrats $28 \mathrm{~d}$ and $28 \mathrm{e}$, the number of species was very low ( $=1$ each) in 1998, but increased to 5 to 10 in the following years, and was 8 and 7 respectively in 2004. Table 4 lists the species and their percent cover in quadrat 28c from 1988 to 2001, 2002 and 2004. In 1998 the number of species in each quadrat ranged from 


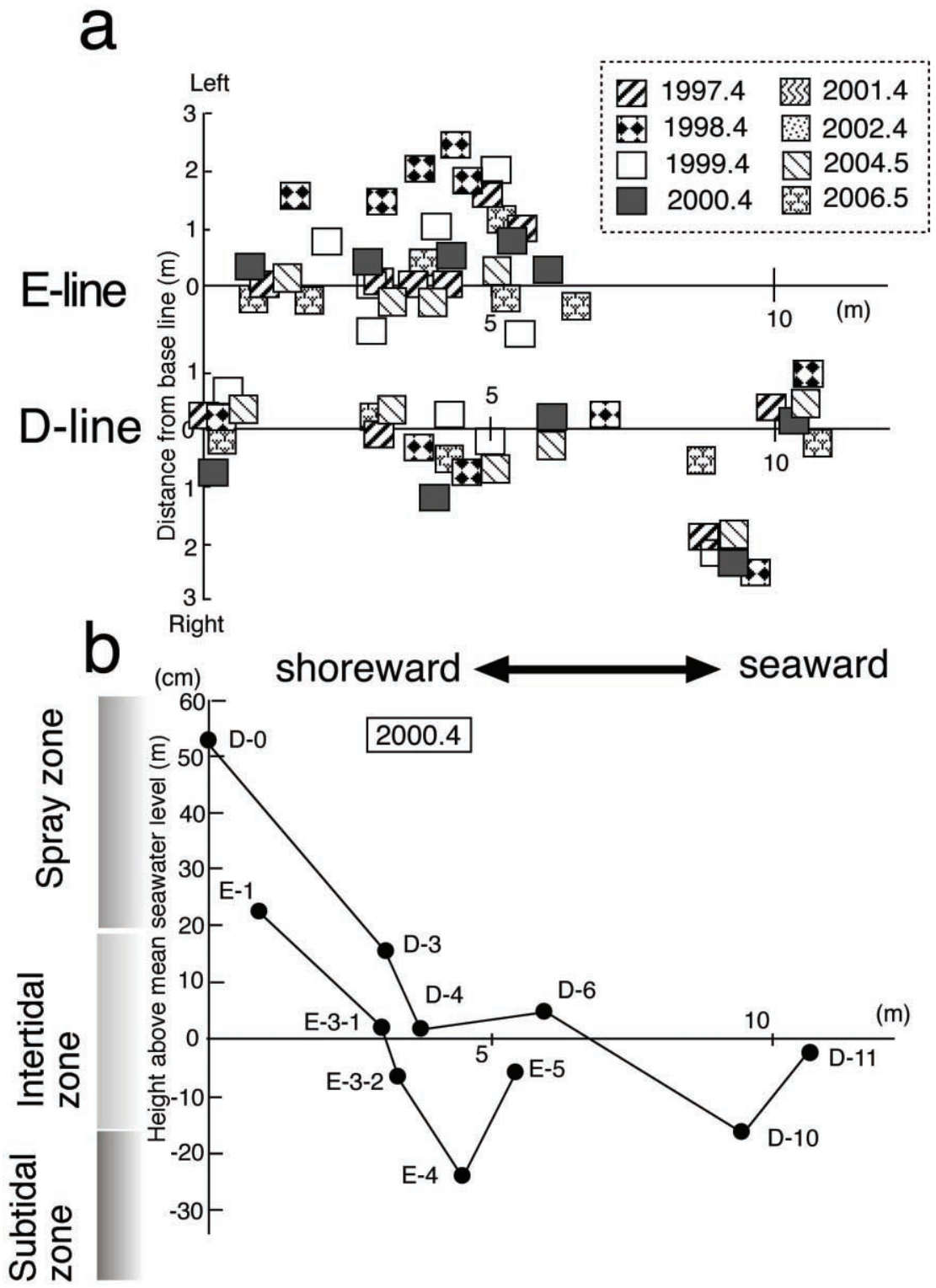

Fig. 4. Horizontal (a) and vertical (b) positions of destructive sampling quadrats along D and E lines (transect lines perpendicular to the shoreline) in Imago-ura, Kasumi. a, Overlay of sampling from April 1997 to April 2006. b, Quadrat vertical positions of April 2000 as examples.

1 to 5 (total cover of $10 \%$ maximum) and included no large macroalgae such as Sargassum. The number of species increased during 1999 and 2000, and the total cover also increased to 10-35\%. From 2000, Sargassum species appeared in some quadrats and remained in 2001.

\section{DISCUSSION}

From the monitoring data, it became clear that the damage by oil pollution to macroalgal vegetation was most severe in the upper intertidal zone. As shown in Fig. 5, rapid recovery in species numbers occurred with- in a year of the disaster in the quadrats (E-3-2 and E-4) of the intertidal zone that were located farther from the shoreline (3-6 $\mathrm{m}$ from the starting point of the transect lines). The number of macroalgal species remained in the same ranges in 2004 and 2006 for this zone. In contrast, it took two years for the species number to increase in the quadrats of the upper intertidal and the lower spray zone (E-1), located closer to the starting point of the transect lines $(0-1 \mathrm{~m})$. However, the vegetation declined again in 1999 and disappeared in 2002, and was not seen in the following year. Therefore, this increase (recovery) could be a temporary phenomenon caused by the reduction in herbivores due to the oil pollution. 


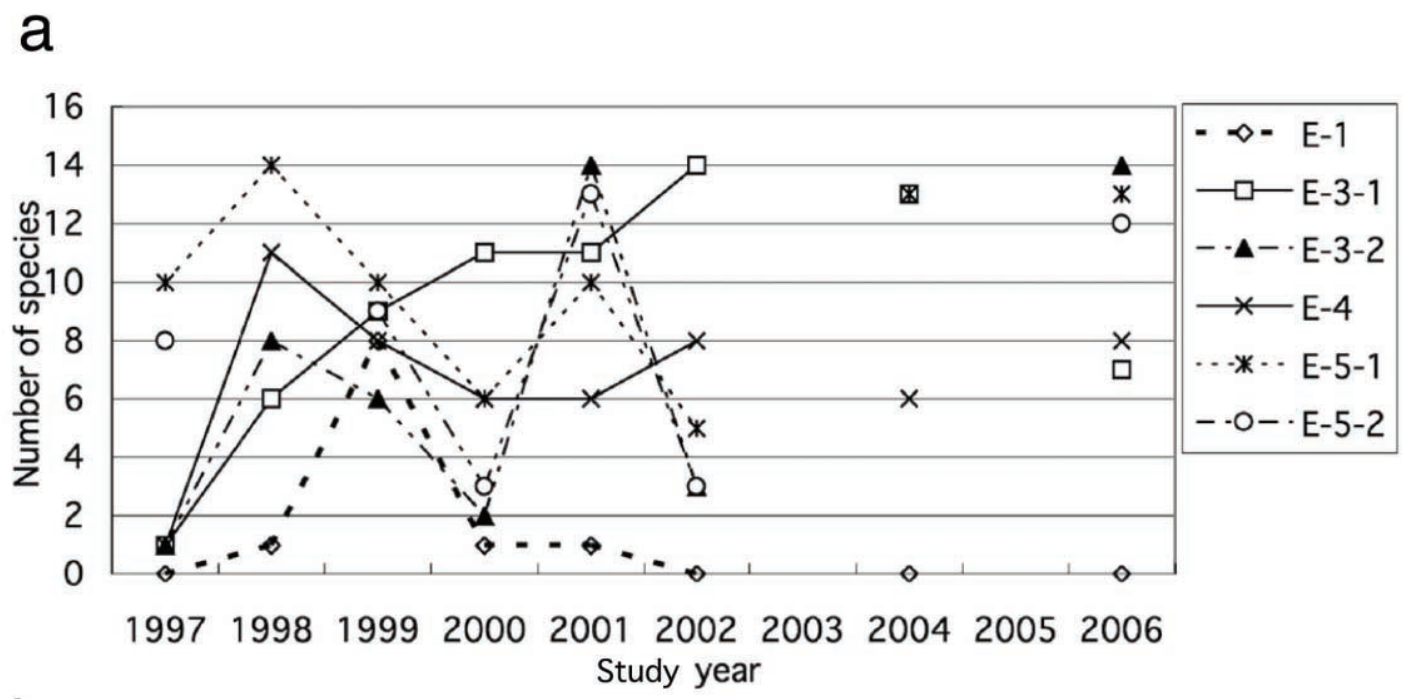

b

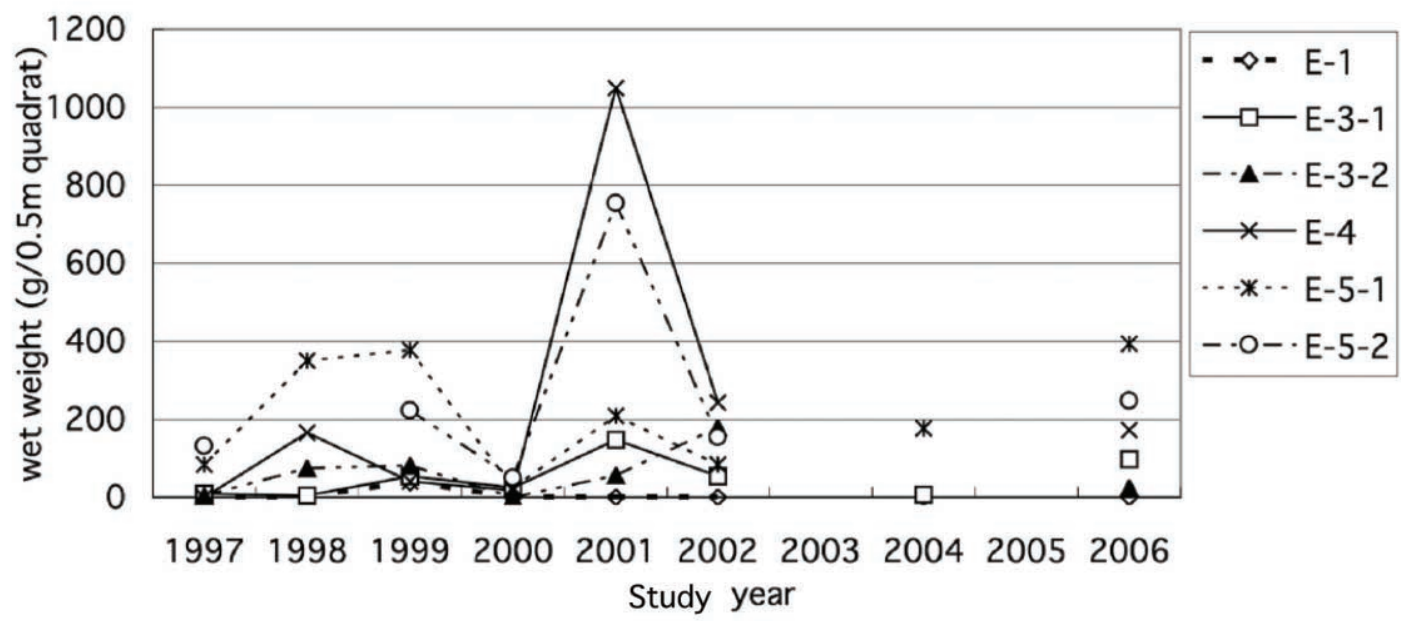

Fig. 5. Succession of number of species (a) and wet weight (b) of macroalgae in $0.5 \times 0.5 \mathrm{~m}$ quadrats in Line D and E in Imago-ura from 1997 to 2006. No data were available for 2003 and 2005.

The slow recovery of these higher sites was also demonstrated in the succession data of quadrat 28 along the transect line paralleling the shoreline (Tables 3,4 ). It is noteworthy that here again the recovered vegetation declined in years 2 or 3 after the spill (Figs $5 a, b$ ). The reduction of herbivores by the pollution might have initially accelerated recovery of the macroalgal vegetation, but subsequent delayed recovery of herbivores might have then reduced the numbers of species and the biomass of the algae in later years.

Because of the lack of baseline data on the macroalgal vegetation at the study sites, it was difficult to determine the normal (undisturbed) state of the vegetation. However, considering the fluctuating patterns at the heavily polluted sites and the unpolluted site (data not shown), it appeared to take at least three to four years for the macroalgal vegetation at Imago-ura to recover. Since the pollution was apparently more severe in Fukui and Ishikawa Prefectures, we think that a minimum of five years of monitoring is necessary to adequately assess the damage by oil pollution to the intertidal zone, although most monitoring projects ceased within 1-2 year(s) after the disaster.

At Imago-ura, the upper intertidal zone, where large amounts of the oil was stranded, suffered the heaviest damage and experienced the slowest recovery. These results agree with observations from other disasters (Neushul 1972; Thomas 1973), but differ somewhat from the Exxon Valdez oil spill where the pattern of recovery varied depending on the site (Highsmith et al. 1996; Stekoll et al. 1996). The sharp reduction of the algal vegetation in the intertidal and the lower spray zones at 
Table 3. Yearly change in number of species in each quadrat $(1 \times 1 \mathrm{~m})$ and the degree of pollution at the study site (++, heavily polluted; +, less heavily polluted). "_" means no data.

\begin{tabular}{|c|c|c|c|c|c|c|c|}
\hline Quadrat number & Degree of oil pollution & 1998.5. & 1999.5. & 2000.5 & 2001.5 & 2002.5 & 2004.5 \\
\hline $26 a$ & ++ & 5 & 10 & 9 & 5 & 5 & 11 \\
\hline $26 \mathrm{~b}$ & ++ & 7 & 7 & 7 & 5 & 7 & 8 \\
\hline $26 c$ & ++ & 5 & 5 & 7 & 3 & 8 & 6 \\
\hline $26 \mathrm{~d}$ & ++ & 3 & 6 & 7 & 6 & 5 & 8 \\
\hline $26 \mathrm{e}$ & ++ & 4 & 5 & 6 & 5 & 7 & 7 \\
\hline $27 \mathrm{a}$ & ++ & 2 & 4 & 5 & 1 & 7 & 5 \\
\hline $27 \mathrm{~b}$ & ++ & 7 & 5 & 8 & 7 & 4 & 15 \\
\hline $27 c$ & ++ & 6 & 5 & 4 & 5 & 6 & 13 \\
\hline $27 \mathrm{~d}$ & ++ & 6 & 6 & 5 & 5 & 6 & 10 \\
\hline $27 \mathrm{e}$ & ++ & 4 & 6 & 6 & 6 & 7 & 7 \\
\hline $28 \mathrm{a}$ & ++ & 4 & 5 & 4 & 8 & - & 6 \\
\hline $28 \mathrm{~b}$ & ++ & 5 & 5 & 7 & 7 & - & 7 \\
\hline $28 c$ & ++ & 3 & 5 & 7 & 8 & - & 7 \\
\hline $28 \mathrm{~d}$ & ++ & 1 & 2 & 10 & 10 & - & 8 \\
\hline $28 \mathrm{e}$ & ++ & 1 & 5 & 3 & 5 & - & 7 \\
\hline $29 a$ & ++ & 5 & 8 & 6 & 4 & - & 5 \\
\hline $29 \mathrm{~b}$ & ++ & 3 & 10 & 7 & 4 & - & 10 \\
\hline $29 \mathrm{c}$ & ++ & 4 & 9 & 6 & 5 & - & 11 \\
\hline $29 \mathrm{~d}$ & ++ & 3 & 7 & 5 & 7 & - & 10 \\
\hline $29 \mathrm{e}$ & ++ & 7 & 7 & 6 & 7 & - & 5 \\
\hline $30 a$ & ++ & 9 & 10 & 9 & 5 & - & 9 \\
\hline $30 \mathrm{~b}$ & ++ & 10 & 10 & 7 & 8 & - & 13 \\
\hline $30 \mathrm{c}$ & ++ & 6 & 6 & 7 & 6 & - & 16 \\
\hline $30 \mathrm{~d}$ & ++ & 1 & 1 & 5 & 1 & - & 3 \\
\hline $30 \mathrm{e}$ & ++ & 10 & 10 & 5 & 5 & - & 13 \\
\hline $31 a$ & ++ & 11 & 10 & 9 & 12 & 14 & 14 \\
\hline $31 b$ & ++ & 5 & 7 & 8 & 5 & 15 & 13 \\
\hline $31 \mathrm{c}$ & ++ & 10 & 10 & 7 & 9 & 8 & 16 \\
\hline $31 d$ & ++ & 12 & 11 & 4 & 4 & 12 & 12 \\
\hline $31 \mathrm{e}$ & ++ & 8 & 12 & 7 & 4 & 11 & - \\
\hline $32 a$ & ++ & 2 & 6 & 1 & 5 & 5 & - \\
\hline $32 b$ & ++ & 2 & 1 & 2 & 2 & 2 & - \\
\hline $32 c$ & ++ & 3 & 5 & 2 & 5 & 3 & - \\
\hline $32 \mathrm{~d}$ & ++ & 5 & 6 & 4 & 5 & 5 & - \\
\hline $32 \mathrm{e}$ & ++ & 5 & 5 & 7 & 3 & 5 & - \\
\hline $33 a$ & + & 5 & 7 & 7 & 3 & 3 & - \\
\hline $33 b$ & + & 8 & 5 & 4 & 4 & 5 & - \\
\hline $33 c$ & + & 8 & 5 & 8 & 4 & 1 & - \\
\hline $33 \mathrm{~d}$ & + & 8 & 6 & 7 & 4 & 4 & - \\
\hline $33 e$ & + & 8 & 6 & 11 & 3 & 2 & - \\
\hline
\end{tabular}

Imago-ura (Figs 5a, b) was similar to the phenomenon observed in the Exxon Valdez disaster in Fucus populations (Driskell et al. 2001), where the Fucus cover at spilldisturbed sites was initially reduced after the disaster in 1989 but rapidly increased to above normal levels, then subsequently dropped in 1994-1995.

\section{ACKNOWLEDGEMENT}

We are grateful to Eric Henry and Sandra Lindstrom for reading and improving the English of the manuscript, and technical staffs and students of Kobe University Research Center for Inland Seas, volunteer staffs of the Takeno Snorkel Center, and the National 
Table 4. Succession of macroalgal vegetation (list of species and \% coverage) of quadrat $28 \mathrm{c}$ in Imago-ura, one of the most heavily polluted sites.

\begin{tabular}{|c|c|c|c|c|c|c|c|c|c|c|}
\hline May, 1998 & $\%$ & May, 1999 & $\%$ & May, 2000 & $\%$ & May, 2001 & $\%$ & May, 2002 & \% May, 2004 & $\%$ \\
\hline Chondrus nipponicus & + & Crustose corallines & 15 & Crustose corallines & 10 & ${ }^{*}$ Ralfsia sp. & 10 & Caulacanthus ustulatus & 5 Crustose corallines & 20 \\
\hline Grateloupia filicina & + & Gelidium capillacea & 5 & Gelidium divaricatum & 5 & *Sargassum hemiphyllum & 5 & Cladophora sp. & + Pterocladiella tenuis & 10 \\
\hline \multirow[t]{6}{*}{ Crustose corallines } & + & Chondrus nipponicus & 5 & *Ulva pertusa & + & Cladophora sp. & 5 & Crustose corallines & $+{ }^{*}$ Ralfsia sp. & + \\
\hline & & Cladophora sp. & + & *Sargassum hemiphyllum & + & *Dictyota dichotoma & + & & Carpopeltis prolifera & + \\
\hline & & Gelidium divaricatum & + & Chondrus nipponicus & + & Gelidium capillacea & + & & Cladophora sp. & + \\
\hline & & & & Sargassum sp. & + & Chondrus nipponicus & + & & Chondrus nipponicus & + \\
\hline & & & & Grateloupia filicina & + & Gelidium divaricatum & + & & Gelidium divaricatum & $n+$ \\
\hline & & & & & & Crustose corallines & + & & & \\
\hline
\end{tabular}

Park Resort Village Takeno-kaigan, Japan for supporting the field studies. A part of this study was supported by the Natural Conservation section of the Hyogo Prefectural Office, Japan and the International Exchange Program of Kobe University.

\section{REFERENCES}

Clark R.B. 1997. Marine Pollution. Fourth Edition. Oxford University Press, Oxford.

Driskell W.B., Ruesink J.L., Lees D.C., Houghton J.P. and Lindstrom S.C. 2001. Long-term signal of disturbance: Fucus gardneri after the Exxon Valdez oil spill. Ecological Applications 11: 815-827.

Fujiwara H. and Murakami M. 1978. Ecological studies on hydrocarbon-oxidizing bacteria in Japanese coastal waters. 2. Distribution of hydrocarbon-oxidizing bacteria in the oilpolluted areas caused by the Mizushima oil refinery accident. Bull. Jpn. Soc. Sci. Fish. 44: 91-104.

Kuroda K., Baba, N. and Takahashi H. 1978. Hydrographic conditions in Harimanada of the Seto Inland Sea with reference to chemical elements and plankton in February 1975. Bull. Kobe Mar. Observatory 196: 14.

Hayashi I., Konno T. and Yamakawa H. 2000. Distributional characteristics of benthic organisms in shallow sublittoral rocky areas of Mikuni, Fukui Prefecture: part of the survey on he effects of the NAKHODKA oil spill. Bulletin of Japan Sea Nat. Fish. Res. Inst. 50: 43-137.

Highsmith R.C., Rucker T.L., Stekoll M. S., Saupe S.M., Lindeberg M.R., Jenne R.N. and Erickson W.P. 1996. Impact of the Exxon Valdez oilspill on intertidal biota. American Fisheries Society Symposium 18: 212-237.

Komatsu T., Nakaoka M., Kawai H., Yamamoto T., Marine Life Research Group of Takeno and Ohwada K. 2003. Impacts of the NAKHODKA heavy-oil spill on an intertidal ecosystem: An approach to impact evaluation with geographical information system. Mar. Poll. Bull. 47: 99-104.

Neushul M. 1972. The effects of pollution on populations of intertidal and subtidal organisms in southern California. Santa Barbara Oil Symposium Proceedings. U.S. Government Printing Office, Washington D.C. pp.165-172.

Peterson C.H. 2001. The Exxon Valdes oil spill in Alaska: Acute, indirect and chronic effects on the ecosystem. Adv. Mar. Biol. 39: 1-103.

Peterson C.H., McDonald L.L., Green R.H. and Erickson W. P. 2001. Sampling design begets conclusions: the statistical basis for detection of injury to and recovery of shoreline communities after the 'Exxon Valdez' oil spill. Mar. Ecol. Prog. Ser. 210: 255-283.

Peterson C.H., Rice S.D., Short W., Esler D., Bodkin J.L., Ballachey B.E. and Irons D.B. 2003. Long-term ecosystem response to the Exxon Valdez Oil Spill. Science 302: 2082-2086.

Southwood A.J. and Southward E.C. 1978. Recolonization of rocky shores in Cornwall after the use of toxic dispersants to clean up the Torrey Canyon spill. J. Fish. Res. Board Canada 35: 682-706.

Stekoll M.S., Deysher L., Highsmith R.C., Saupe S.M., Guo Z., Erickson W.P., McDonald L. and Strickland D. 1996. Coastal habitat injury Assessment: intertidal communities and the Exxon Valdez oil spill. American Fisheries Society Symposium 18: 177-192.

Tazaki K. 2003. The environmental impacts on heavy oil spilled from the wrecked Russian tanker Nakhodka attacked the coast of Hokuriku district, Japan, in 1997. In: Tazaki K. (ed.), Heavy Oil Spilled from Russian Tanker "Nakhodka" in 1997: Towards edo-responsibility, Earth Sense. 21st Century COE Kanazawa University. pp. 1-46.

Thomas M.L.H. 1973. Effects of bunker C oil on intertidal and lagoonal biota in Chedabucto Bay, Nove Scotia. J. Fish. Res. Board of Canada 30: 83-90.

Yamamoto T. Komatsu T., Kawai H., Nakaoka M., Marine Life research Group of Takeno and Ohwada K. 2003. Impact and recovery of an intertidal ecosystemfrom the Nakhodka heavyoil spill. In: Tazaki K. (ed.), Heavy Oil Spilled from Russian Tanker "Nakhodka" in 1997: Towards edo-responsibility, Earth Sense. 21st Century COE Kanazawa University. pp. 162-173.

Yamamoto T., Nakaoka M., Komatsu T., Kawai H., Marine Life Research Group of Takeno and Ohwada K. 2003. Impacts of the NAKHODKA heavy-oil spill on an intertidal ecosystem: Recovery of animal community. Mar. Poll. Bull. 47: 91-98.

Yajima T. 1997. Heavy-oil spill and inter-tidal organisms. Kaiyo Monthly 29: 623-627. (in Japanese)

Received 5 February 2007

Accepted 25 February 2007 